\title{
Psoroptes ovis infestation of sheep in São Vicente do Sul, Rio Grande do Sul, Brazil
}

\author{
José Osvaldo Jardim Filho ${ }^{1,2}$ Gisane Lanes de Almeida ${ }^{3}$ (i) José Vitor Marcon Piazer $^{3}$ (1) \\ Luiza Jacondino Rodegheri ${ }^{(1)}$ Nathálie Bonotto Ruivo $^{4(-)}$ Brenda Serrano Pires $^{5}$ (i) \\ Marta Lizandra do Rego Leal ${ }^{1,2^{*}}$ (i)
}

${ }^{1}$ Programa de Pós-graduação em Medicina Veterinária, Universidade Federal de Santa Maria (UFSM), 97105-900, Santa Maria, RS, Brasil. E-mail: martalizandra@gmail.com. "Corresponding author.

${ }^{2}$ Departamento de Clínica de Grandes Animais, Universidade Federal de Santa Maria (UFSM), Santa Maria, RS, Brasil.

${ }^{3}$ Departamento de Defesa Agropecuária da Secretaria da Agricultura, Pecuária e Desenvolvimento Rural do Rio Grande do Sul, Porto Alegre, RS, Brasil.

${ }^{4}$ Programa de Residência Multiprofissional em Saúde e em Área Profissional da Saúde/Medicina Veterinária, Universidade Federal de Santa Maria (UFSM), Santa Maria, RS, Brasil.

${ }^{5}$ Clínica de Ruminantes do Hospital Veterinário Universitário, Universidade Federal de Santa Maria (UFSM), Santa Maria, RS, Brasil.

ABSTRACT: Sheep psoroptic mange is a form of highly itchy and contagious dermatitis caused by the mite Psoroptes ovis. Here, we reporteda case of sheep psoroptic mange outbreak at a property in São Vicente do Sul, Rio Grande do Sul (RS), Brazil. Poor nutritional status, restless behavior, pruritus, wool fall, yellowish crusted skin lesions with edge exudate, erythema surrounding the lesions and presence of wool trapped between the teeth were observed in the herd. Complete blood count test showed marked eosinophilia, and parasitological examination of a skin scrape revealed P. ovis. Histopathological examination of a skin biopsy sample revealed eosinophilic pustular dermatitis. The treatment consisted of two administrations of $1 \%$ ivermectin at $1 \mathrm{~mL} / 33 \mathrm{~kg}$ of body weight subcutaneously over an interval of 10 days. To the best of our knowledge, this is the first report of the occurrence of psoroptic mange at a sheep farm of RS with description of the clinical signs and laboratory and histopathological findings.

Key words: psoroptic mange, Psoroptes ovis, sheep, dermatitis, pruritus.

Sarna psoróptica ovina em São Vicente do Sul, Rio Grande do Sul, Brasil

RESUMO: A sarna psoróptica ovina é uma dermatite altamente pruriginosa e contagiosa causada pelo ácaro Psoroptes ovis. Este trabalho registra o caso da doença em uma propriedade no municipio de São Vicente do Sul, Rio Grande do Sul (RS), Brasil. No rebanho foram observados mau estado de nutrição, comportamento inquieto, prurido, queda de lã, lesões crostosas amareladas na pele com exsudato nas bordas, eritema perilesional e presença de lã presa entre os dentes. O hemograma mostrou marcada eosinofilia e um raspado cutâneo demonstrou a presença de P. ovis no exame parasitológico. No exame histopatológico, oriundo de uma biópsia de pele, observou-se dermatite pustular eosinofilica. O tratamento consistiu de duas administrações de ivermectina a $1 \%$ na dose de $1 \mathrm{ml} / 33 \mathrm{~kg}$ de peso corporal por via subcutânea em um intervalo de 10 dias. Este é primeiro estudo relatando a ocorrência, sinais clínicos e achados laboratoriais/histopatológicos da sarna psoróptica em uma propriedade de criação de ovinos no RS.

Palavras-chave: sarna psoróptica, Psoroptes ovis, ovino, dermatite, prurido.

Sheep psoroptic mange is a severe sheep skin disease (LOSSON, 2012), characterized by highly itchy dermatitis, which causes intense anxiety in the animal. The affected sheep scratch themselves frantically, bite the affected area, rub into fences, and brush the pelvic limb hooves over the lesions
(CORKE \& BROOM, 1999). The etiologic agent of this disease is the mite Psoroptes ovis of the family Psoroptidae (WALL \& KOLBE, 2006).

The biosystematic status of mite species belonging to the genus Psoroptes is difficult to determine through phenotypic methods and has been 
subject to taxonomic revisions and ongoing debate. Five species P. cuniculi, P. ovis, P. equi, P. cervinus, and $P$. natalensis are generally believed to belong to this genus. However, the conspecificity of the members of the genus Psoroptes is supported by molecular genetic analyses (ZAHLER et al., 2000). The first Psoroptes mite described is $P$. ovis and should, therefore, carry taxonomic priority for the synonymized genus (WALL \& KOLBE, 2006).

This disease is transmitted through direct contact between animals and by fomites, such as fences, hoppers, and trucks (SPICKLER, 2009). This disease is highly contagious and responsible for huge economic losses (LOSSON, 2012). These losses are related to damage caused to wool quality (MOZAFFARI \& DERAKHSHANFAR, 2009), suppression of weight gain in growing animals, weight loss in adult animals, and, in some cases, death of severely debilitated animals (URQUHART et al., 1998). However, P. ovis does not infest humans (SPICKLER, 2009).

A few countries, including the United States, Canada, and New Zealand, have managed to eradicate psoroptic mange. In the United Kingdom the disease was eradicated in 1952 but re-introduced in 1973 (LOSSON, 2012), and multiple resistance to macrocyclic lactones was described in $P$. ovis from the outbreak in Wales and south-west England (STURGESS-OSBORNE et al., 2019). In Brazil, the disease is on the list of compulsory notifications to the Official Veterinary Service (SVO) (MAPA, 2013), Rio Grande do Sul (RS), the only Federation Unit that has its own regulation to combat sheep mange (MACHADO et al., 2014; RS, 1993). In RS, the disease reached the limits of eradication at the beginning of the $21^{\text {st }}$ century, increasing in 2010 in the city of Santana do Livramento, when cases of this disease were coincidentally detected in Uruguay (MACHADO et al., 2014; VIEIRA et al., 2013). In addition to sheep, the mite $P$. ovis also infests goats in the Brazilian semiarid region (DE AMORIM et al., 2015).

To the best of our knowledge, this is the first report of the occurrence of sheep psoroptic mange at a property of the Midwest Rio Grande do Sul region. A 10-month-old male Polwarth sheep from a property in São Vicente do Sul, RS, was admitted to the Ruminant Clinic of the University Veterinary Hospital (HVU) from the Federal University of Santa Maria (UFSM). In the anamnesis, the owner reported that several sheep, including this one, at his property had been showing restless behavior, wool fall and itching since 2017. On physical examination, the animal showed poor nutrition status, restless behavior, and intense itching at various regions of the body. The sheep scratched, nibbled, and rubbed (on the trough and walls of the stall) the injured regions and used the pelvic limb hooves to rub the lesions. Some areas of the body had loss of wool and yellow scabs on the skin that, when removed, exhaled a foul odor (Figure 1A). Further, clinical thermometry revealed that the animal had fever.

A blood sample was referred for a blood count test, which showed marked eosinophilia $(3,293$ eosinophils/ $\mu \mathrm{L}$ ). A skin scrape was collected from the skin lesions and sent for laboratory diagnosis. Parasitological examination showed negative results, and microbiological examination was positive for Staphylococcus spp. and Corynebacterium spp. Therefore, the animal was treated with antibiotics and steroidal anti-inflammatory drugs. Two weeks later, because there was no clinical improvement, a skin biopsy sample was obtained and sent for histopathological examination, which showed eosinophilic pustular dermatitis. After 6 days, there was no improvement in the clinical condition, so a reevaluation was performed. The animal was sheared, which allowed the observation of intense marginal erythema at the established lesions on the skin. The chewing test reflex was positive, raising the clinical suspicion of sheep psoroptic mange; although, there had been no report of the disease in the region of origin. Subsequently, a second collection of superficial skin scraping was performed from the region marginal to the lesions. The material was sent to the UFSM Parasitology Laboratory, where the presence of the $P$. ovis mite was detected (Figure 1B), confirming the diagnosis of ovine psoroptic mange. Soon after the result, the SVO was notified. For treatment, 1\% ivermectin was administered subcutaneously at a dose of $1 \mathrm{~mL} / 33 \mathrm{~kg}$ of body weight, and after 2 days of treatment, the clinical signs of pruritus disappeared. The administration of a second dose of treatment after 7 days on the property was prescribed.

One day after the notification, the SVO visited the sheep property. On inspection of the property, damage to the fences with accumulation of wool tufts was observed (Figure 1C). Examining the herd of 121 Polwarth and Texel sheep, attention was drawn to restlessness, poor nutrition, wool loss (Figure 1D) and the presence of yellowish crusted skin lesions with exudate on its border in many animals. They scratched themselves frantically, rubbing their bodies against the premises and biting or rubbing the areas of the body that were infested with mange with the hooves of the pelvic limbs. Some animals were in a poor state of nutrition and showed a large amount of 
wool stuck between the teeth (Figure 1E), which was probably making feeding difficult. On the same day, $1 \%$ ivermectin was administered subcutaneously at a dose of $1 \mathrm{~mL} / 33 \mathrm{~kg}$ of body weight throughout the herd, which was repeated after 10 days. Five weeks later, the herd was re-inspected by the SVO, and the animals were asymptomatic and showed an evident improvement in the body score.

In sheep farming, the concern with sheep psoroptic mange is understandable, as it interferes markedly in the feeding and grazing of the animals, causing great productive losses (MACHADO et al., 2014). The affected sheep are so restless and worried with scratching that they almost stop eating (URQUHART et al., 1998). In this case, damage was caused to the property fences (Figure 1C) because of the pruritus presented by the animals. Beyond the damage already described, this damage may contribute to the economic losses generated by the disease. As the mites move across the surface of the skin, they secrete and excrete allergens and other potent pro-inflammatory factors. This combination of mechanical skin abrasion, allergen deposition and grooming behavior by the host in response to pruritus caused by mites contributes to the subsequent cutaneous inflammatory response (BURGESS et al., 2019). Beyond the intense restlessness caused by the itching, the herd described in this report presented with wool loss (Figure 1D) and formation of yellowish scabs. According to O'BRIEN (1995), yellowish scabs arise with the evolution of the disease after an initial clinical condition of tufted wool. This condition was not observed probably by the chronicity of the disease that had been affecting the herd since 2017, as reported by the owner. The first phase of infestation occurs as a zone of inflammation with small vesicles and serous exudate. As the lesion diffuses, the center becomes dry and covered with a yellow crust, while the edges, where the mites are multiplying, remain moist (URQUHART, 1998). This confirmed the chronicity of the case described, since the lesions reported in the herd were crusted, yellowish and with exudate on the edge.

The perilesional erythema reported in the sheep examined at HVU was probably related to the greater severity at the advancing margin of

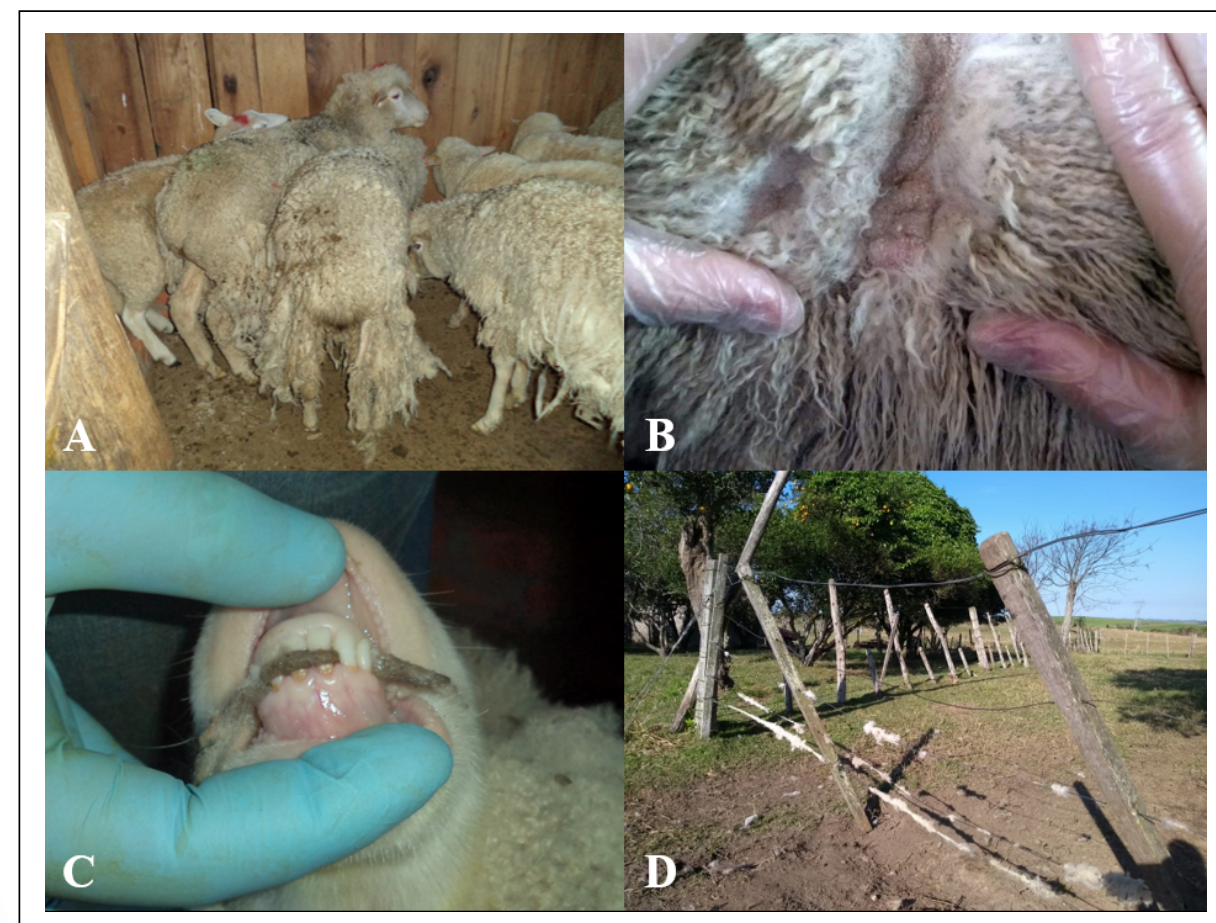

Figure 1 - Sheep psoroptic mange, São Vicente do Sul, Rio Grande do Sul, Brazil. A - Skin injury after crust removal; B - Presence of the $<\mathrm{i}>$ Psoroptes ovis $</ \mathrm{i}>$ mite in superficial skin scraping; $\mathrm{C}$ Damage to fences with accumulation of tufts of wool; D - Sheep with wool fall; E - Presence of accumulated wool between teeth. 
the lesion since the number of mites present in this place was greater than that at the initial site of the infestation. Apparently, P. ovis elicits an early innate cutaneous response that is subsequently augmented by the development of an adaptive immune response, the intensity of which corresponds to the local population density of mites (VAN DEN BROEK et al., 2004). In this sheep, the skin biopsy also revealed eosinophilic dermatitis mentioned by MOZAFFARI \& DERAKHSHANFAR (2009) but it was followed by pustular dermatitis, which probably resulted from secondary bacterial infections, given the positive result for Staphylococcus spp. and Corynebacterium spp. in the microbiological examination of the first skin scrapings performed. BATES (2003) investigated the skin flora of sheep with and without $P$. ovis and observed, among other findings, that Staphylococcus epidermidis were present in both, but Corynebacterium species were isolated only from infested wool or skin. These secondary infections were probably responsible for the foul odor after scab removal (Figure 1A).

Some sheep affected by the psoroptic mite show a nibbling reflex without any external stimulation, and the most affected sheep exhibit this reflex when they touch the dorsal region, given that some may fall in lateral decubitus, with opisthotons and chewing movements that may last up to $10 \mathrm{~min}$ (SPICKLER, 2009). The nibbling reflex was positive in the sheep treated at the HVU on touching his dorsal region but without decubitus. O'BRIEN et al. (1995), in an experimental infestation of sheep with P. ovis, observed marked eosinophilia 9 weeks after the deposition of 100 parasites on sheep wool. This marked eosinophilia was also observed in the sheep admitted to HVU.

Although, weight loss and body condition are attributed to the distraction caused by intense pruritus, which reduces feeding, the presence of wool trapped between the teeth was observed in some sheep with a poor nutritional status (Figure 1E). This finding was previously unreported, which may have brought difficulty in grasping food, intensifying weight loss in these animals. The weight loss of parasitized animals, which was also described by LOSSON (2012), was observed in the entire herd of the property, which showed weight gain after treatment. Treatment with $1 \%$ ivermectin in a two-dose protocol, at intervals of 7 to 10 days, is the standard procedure for SVO (VIEIRA et al., 2013), which was followed for the animals of the property described.

Here, we reported the occurrence of sheep psoroptic mange at a rural property located in the mesoregion of the Midwestern Rio Grande do Sul region, describing the clinical and laboratory and histopathological findings observed. There are no other published scientific studies reporting the occurrence of this disease, its clinical signs, or laboratory or histopathological findings in this region; although, its occurrence has been recorded in the state by the Official Veterinary Service (MACHADO et al, 2014; VIEIRA et al, 2013). This lack of information is probably contributing to the difficulty in diagnosing sheep scab in RS by veterinarians working at rural properties in the state. In conclusion, researchers should investigate the occurrence of this parasitic infection in RS and performed characterization of its clinical manifestation to better guide professionals, thus contributing to its control.

\section{ACKNOWLEDGEMENTS}

This work was financed in part by the Coordenação de Aperfeiçoamento de Pessoal de Nível Superior (CAPES), Brasil - Finance code 001."

\section{BIOETHICS AND BIOSSECURITY COMMITTEE APPROVAL}

This study was not submitted to the Animal Use Ethics Committee for not being a scientific experimentation, but only routine clinical examination findings.

\section{DECLARATION OF CONFLICT OF INTERESTS}

The authors declare no conflict of interest. The founding sponsors had no role in the design of the study; in the collection, analyses, or interpretation of data; in the writing of the manuscript, and in the decision to publish the results.

\section{AUTHORS' CONTRIBUTIONS}

The authors contributed equally to the manuscript.

\section{REFERENCES}

BATES, P. Bacterial associations with the sheep scab mite (Psoroptes ovis). Veterinary Record,v.152,n.7,p.206-208,2003.Available from: $\quad<$ https://veterinaryrecord.bmj.com/content/152/7/206>. Accessed: Mar. 28, 2020. doi: 10.1136/vr.152.7.206.

BURGESS, S. T. G. et al. A genomic analysis and transcriptomic atlas of gene expression in Psoroptes ovis reveals feeding- and stage-specific patterns of allergen expression. BMC Genomics, v.20, n.1, 756, 2019. Available from: <https://www.ncbi.nlm.nih. gov/pmc/articles/pmid/31640546/> . Accessed: Mar. 26, 2020. doi: 10.1186/s12864-019-6082-6.

CORKE, M. J.; BROOM, D. M. The behaviour of sheep with sheep scab, Psoroptes ovis infestation. Veterinary Parasitology, v.83, n.3- 
4, p.291-300, 1999. Available from: <https://www.sciencedirect. com/science/article/pii/S0304401799000655?via\%3Dihub>. Accessed: Jun. 09, 2019. doi: 10.1016/S0304-4017(99)00065-5.

DE AMORIM, M.G.R. et al. Seasonal prevalence and mean intensity of Psoroptes ovis infestation in goats in the Brazilian semiarid region. Brazilian Journal of Veterinary Parasitology, v.24, n.1, p.59-65, 2015. Available from: <http://www.scielo.br/ pdf/rbpv/v24n1/1984-2961-rbpv-24-1-59.pdf>. Accessed: Mar. 28, 2020. doi: 10.1590/S1984-29612014094.

LOSSON, B. J. Sheep psoroptic mange: An update. Veterinary Parasitology, v.189, n.1, p.39-43, 2012. Available from: $<$ https://www.sciencedirect.com/science/article/pii/ S0304401712001549?via\%3Dihub>. Accessed: Jun. 09, 2019. doi: 10.1016/j.vetpar.2012.03.030.

MACHADO, G. et al. Notificações de doenças de ovinos recebidas pelo Serviço Veterinário Oficial do Rio Grande do Sul nos anos de 2011 e 2012. Porto Alegre: Departamento de Defesa Agropecuária, 2014. 11p. (Informativo Técnico, n.4, ano 5). Online. Available from: <https:/www.agricultura.rs.gov.br/ upload/arquivos/201612/02101308-inftec-49-notif-em-ovinos. pdf $>$. Accessed: Jun. 09, 2019.

MAPA. Instrução Normativa $\mathrm{N}^{0} \mathbf{5 0}$, de 24 de setembro de 2013. Online. Available from: <http://www.agricultura. gov.br/assuntos/sanidade-animal-e-vegetal/saudeanimal/arquivos-das-publicacoes-de-saude-animal/ Listadedoencasanimaisdenotificacaoobrigatoria.pdf $>$. Accessed: Jun. 09, 2019.

MOZAFFARI, A. A.; DERAKHSHANFAR, A. Localized seborrheic dermatitis with hyperhidrosis due to mite infestation in an Iranian cross-breed ram. Pakistan Journal of Biological Sciences, v.12, n.2, p.186-188, 2009. Available from: <https:// scialert.net/abstract/?doi=pjbs.2009.186.188>. Accessed: Jun. 09, 2019. doi: 10.3923/pjbs.2009.186.188.

O'BRIEN, D. J. et al. Haematology and blood biochemistry during the course of psoroptic scabies in sheep. Veterinary Research Communications, v.19, n.1, p.39-48, 1995. Available from: $\quad<$ https://link.springer.com/article/10.1007/BF01839250>. Accessed: Jun. 09, 2019. doi: 10.1007/BF01839250.

RS. Decreto $N^{0}$ 34.869, de 31 de agosto de 1993. Online. Available from: <https://www.agricultura.rs.gov.br/upload/ arquivos/201707/26142825-decreto-34-869-sarna.pdf > . Accessed: Jun. 09, 2019.

SPICKLER, A. R. Sarna ovina. The Center for Food Security \& Public Health, Iowa State University, Ames, 2009. Online. Available from: <http://www.cfsph.iastate.edu/ Factsheets/es/sheep scab psoroptes ovis-es.pdf $>$. Accessed: Jun. 09, 2019.

STURGESS-OSBORNE, C. et al. Multiple resistance to macrocyclic lactones in the sheep scab mite Psoroptes ovis. Veterinary Parasitology, v.272, p.79-82, 2019. Available from: $\quad<$ https://www.sciencedirect.com/science/article/abs/pii/ S0304401719301700?via\%3Dihub>. Accessed: Mar. 28, 2020. doi: 10.1016/j.vetpar.2019.07.007.

URQUHART, G. M. et al. Parasitologia Veterinária. Rio de Janeiro: Guanabara Koogan, 1998. 2ed. 273p.

VAN DEN BROEK, A. H. M et al. Early innate and longer-term adaptive cutaneous immunoinflammatory responses during primary infestation with the sheep scab mite, Psoroptes ovis. Journal of Comparative Pathology, v.131, n.4, p.318-329, 2004. Available from: <https://www.sciencedirect.com/science/ article/abs/pii/S0021997504000702?via\%3Dihub>. Accessed: Mar. 26, 2020. doi: 10.1016/j.jcpa.2004.05.005.

VIEIRA, A. M. et al. Caracterização da situação sanitária do rebanho ovino no município de Santana do Livramento. Porto Alegre: Departamento de Defesa Agropecuária, 2013. 7p. (Informativo Técnico, n.1, ano 4). Online. Available from: $<$ https:// www.agricultura.rs.gov.br/upload/arquivos/201612/02101318inftec-35-caracterizacao-da-ovinocultura-em-Ssantana-doLivramento.pdf>. Accessed: Jun. 09, 2019.

WALL, R.; KOLBE, K. Taxonomic priority in Psoroptes mange mites: P. ovis or P. equi? Experimental and Applied Acarology, v.39, n.2, p.159-162, 2006. Available from: <https://link.springer. com/article/10.1007/s10493-006-9000-y>. Accessed: Mar. 18, 2020. doi: 10.1007/s10493-006-9000-y.

ZAHLER, M. et al. Species of the genus Psoroptes (Acari: Psoroptidae): A taxonomic consideration. Experimental and Applied Acarology, v.24, n.3, p.213-225, 2000. Available from: <https://link.springer.com/article/10.1023\% 2FA\%3A1006443722815>. Accessed: Mar. 18, 2020. doi: 10.1023/A:1006443722815. 